\title{
Protective Effect of Kolaviron, a Biflavonoid from Garcinia kola Seeds, in Brain of Wistar Albino Rats Exposed to Gamma-Radiation
}

\author{
Oluwatosin Adekunle AdARAMOYE \\ Drug Metabolism and Toxicology Research Laboratories, Department of Biochemistry, College of Medicine, Faculty of \\ Basic Medical Sciences, University of Ibadan; Ibadan-20005, Nigeria. \\ Received June 12, 2009; accepted October 10, 2009; published online November 6, 2009
}

\begin{abstract}
This study was designed to evaluate the protective effect of kolaviron (KV), a biflavonoid from Garcinia kola seeds, against $\gamma$-radiation ( 5 Gy)-induced oxidative stress in brain of Wistar rats. Vitamin C (VC) served as standard antioxidant. Forty-four rats were divided into 4 groups of 11 animals each. One group was un-irradiated (normal), two groups were treated with $\mathrm{KV}$ and $\mathrm{VC}(250 \mathrm{mg} / \mathrm{kg})$ for 6 weeks prior to and 8 weeks after irradiation, and fourth group was only irradiated. Rats were sacrificed 1 and 8 weeks after irradiation. Cellular alterations were monitored using changes in the levels of malondialdehyde (MDA) — an index of lipid peroxidation, superoxide dismutase (SOD), glutathione-S-transferase (GST), reduced glutathione (GSH), catalase (CAT), alanine and aspartate aminotransferases (ALT and AST), urea and creatinine. MDA levels increased significantly $(p<0.05)$ by $90 \%$ and $151 \%$ after 1 and 8 weeks of irradiation. Furthermore, levels of GSH and antioxidant enzymes were significantly $(p<0.05)$ decreased in $\gamma$-irradiated animals. GSH and GST decreased by $61 \%$ and $43 \%$ after 1 week, and by $75 \%$ and $74 \%$, after 8 weeks of exposure, respectively. $\gamma$-Irradiation decreased SOD and CAT levels by $53 \%$ and $68 \%$, respectively, and caused significant $(p<0.05)$ increases in serum ALT, AST and urea after 8 weeks of exposure. Treatment with KV and VC significantly decreased the levels of MDA, ALT, AST and urea. The antioxidant indices were significantly ameliorated in KV-treated animals. These data suggest that kolaviron may protect against $\boldsymbol{\gamma}$-radiation-induced oxidative stress in brain of exposed rats.
\end{abstract}

Key words antioxidant enzyme; brain; radioprotection; kolaviron; vitamin C

Ionizing radiation is an important environmental risk factor for various cancers and also a major therapeutic agent for cancer treatment. Exposure of mammalian cells to radiation induces several types of damage to DNA, including double and single-strand breaks, base and sugar damage, as well as DNA-DNA and DNA-protein cross-links. ${ }^{1)}$ During radiotherapy, ionizing radiation interacts with biological systems to induce excessive oxygen free radicals or reactive oxygen species (ROS), which attack various cellular components including DNA, proteins and membrane lipids, thereby leading to significant cellular damage. ROS also negatively affects intracellular concentration of antioxidants. ${ }^{2)}$ The major types of ROS or ROS-producing species generated by radiation are superoxide anion $\left(\mathrm{O}_{2}^{--}\right)$, hydrogen peroxide $\left(\mathrm{H}_{2} \mathrm{O}_{2}\right)$, and hydroxyl $\left(\mathrm{OH}^{*}\right)$ radicals. ${ }^{3)}$ ROS present a paradox in their biological functions: on one hand, they prevent diseases by assisting the immune system, mediating cell signaling and playing an essential role in apoptosis. On the other hand, they can damage many biologically active molecules, leading to tissue damages and cell death, ${ }^{4,5}$ other side effects of irradiation include; nausea, vomiting, diarrhea, etc. ${ }^{6}$ Therefore, the design of strategies capable of protecting normal tissues from the lethal actions of radiation is of great interest in radiation biology.

Plants have been the companion of man and formed the basis of useful drugs for the treatment of various ailments. The use of plants may be beneficial in protecting against the radiation-induced damage, since they are less toxic than synthetic compounds at their optimum doses. ${ }^{7)}$ Therefore, screening of plants present a major avenue for the discovery of new radioprotective drugs. A number of radioprotective compounds that have been identified from medicinal plants are known to elicit strong antioxidant potentials, these include; Phyllantus amaurus, Tinospora cordifolia, Hibiscus sabdariffa, Aaegle marmelos, Vernonia amygdalina, Amarathus paniculatus, etc. ${ }^{8-12)}$ In view of the above, it is pertinent to look inwards to other medicinal plants that can protect against radiation.

Garcinia kola Heckel (family Guttiferae) is a herb grown in Nigeria and has a characteristic astringent, bitter and resinous taste. Extracts of the plant are used in ethnomedicine to treat laryngitis, cough and liver diseases. ${ }^{13)}$ Chemical investigations of the seeds revealed the presence of a GB (Garcinia biflavanone)-type biflavonoids, xanthones, triterpenes, benzophenones, cycloartenol and its 24-methylene derivative. ${ }^{14)}$ Kolaviron (KV), the predominant constituent of the kola is a biflavonoid complex containing the $\mathrm{C}-3 / 8^{\prime \prime}-\mathrm{link}$ biflavanones; GB-1, GB-2, GB-la and kolaflavanone. KV has been reported to prevent hepatotoxicity mediated by carbon tetrachloride, paracetamol, thioacetamide, D-galatosamine, Aflatoxin B1 and 2-acetylaminoflourene. ${ }^{15,16)}$ Similarly, Adaramoye et al. ${ }^{17)}$ reported the anti-atherogenic effect of $\mathrm{KV}$ in rats fed on high cholesterol diet. Also, KV has been reported to elicit strong antioxidant activity in both in vivo and in vitro experimental models. ${ }^{18,19)}$ Accordingly, this study was designed to evaluate the role of $\mathrm{KV}$, when given orally, in protecting brain of rats from oxidative stress caused by $5 \mathrm{~Gy}$ of $\gamma$-radiation.

\section{MATERIALS AND METHODS}

Materials Trichloroacetic acid and thiobarbituric acid were purchased from BDH Chemical Ltd., Poole, U.K. Other chemicals were procured from Sigma Chemical Co., Saint Louis, MO, U.S.A. and were of analytical grade and purest quality available.

Preparation of Kolaviron Garcinia kola seeds were obtained commercially in Ibadan, Nigeria and certified at the 
herbarium in the Department of Botany, University of Ibadan, Nigeria, where a voucher specimen already exists (UI-00530). Three kilogram of peeled seeds was sliced, pulverized with an electric blender and air-dried in the laboratory $\left(25-28^{\circ} \mathrm{C}\right)$. Extraction of $\mathrm{KV}$ was achieved by the method of Iwu et al. ${ }^{20)}$ Briefly, powdered seeds were extracted with light petroleum ether (bp $40-60^{\circ} \mathrm{C}$ ) in a soxhlet extractor. The defatted, dried marc was repacked and then extracted with methanol. The extract was concentrated and diluted to twice its volume with distilled water and extracted with ethyl acetate $(6 \times 250 \mathrm{ml})$. The concentrated ethyl acetate fraction gave a yellow solid known as kolaviron (KV) (Fig. 1) with a percentage yield of $6 \%$. Prior to the experiments, KV was dissolved in corn oil at a concentration of $4 \mathrm{~g} / 100 \mathrm{ml}$ overnight. Aliquots of different concentrations were given orally to animals with a gavage needle.

Animals Inbred 8-9 weeks old male Wistar albino rats weighing $235-250 \mathrm{~g}$ were purchased from the Animal House of the Physiology Department, University of Ibadan, Nigeria. The animals were kept in well-ventilated cages at room temperature $\left(28-30^{\circ} \mathrm{C}\right)$. They were maintained on normal laboratory chow (Ladokun Feeds, Ibadan, Nigeria) and water ad libitum. All animal experiments were conducted without anaethesia in the present study and, the protocol conforms to the guidelines of National Institute of Health (NIH publication 85-23, 1985) for laboratory animal care and use.

Irradiation The animals were treated with a single dose of $\gamma$-radiation of $500 \mathrm{rads}(5 \mathrm{~Gy})$. The source of radiation was a ${ }^{60} \mathrm{Co}$ gamma chamber (Model-220, Atomic Energy of Canada Ltd.) used in the Radiotherapy unit of the University College Hospital, Ibadan, Nigeria. The animals were kept in specially designed well-ventilated cages, their movements were restricted and no anaesthesia was administered. The animals were exposed to whole body radiation at a rate of $1.4 \mathrm{~Gy} / \mathrm{min}$ in a field size of about $25 \times 25 \mathrm{~cm}^{2}$ and at a distance of $70 \mathrm{~cm}$ from the source.

Experimental Design Forty four rats were used for the experiment, and the animals were randomly divided into four groups of eleven animals each.

\begin{tabular}{ll}
\hline Groups & \multicolumn{1}{c}{ Treatment } \\
\hline $\mathrm{N}$ & Normal (Un-irradiated animals) \\
$\mathrm{KV}$ & Irradiated animals treated with $\mathrm{KV}$ \\
& $(250 \mathrm{mg} / \mathrm{kg}$ body weight p.o. $)$ \\
$\mathrm{RA}$ & Irradiated control treated with vehicle p.o. \\
$\mathrm{VC}$ & Irradiated animals treated with vitamin C \\
& $(250 \mathrm{mg} / \mathrm{kg}$ body weight p.o. $)$ \\
\hline
\end{tabular}

Animals in the test groups were treated with $\mathrm{KV}$ and $\mathrm{VC}$ for 6 weeks prior to and 8 weeks after irradiation. $\mathrm{KV}$ and $\mathrm{VC}$ were administered orally at a dose of $250 \mathrm{mg} / \mathrm{kg}$ body weight daily. The dose of KV was established from previous experiment in our laboratories. ${ }^{17)} \mathrm{VC}$ was dissolved in water and $\mathrm{KV}$ in corn oil (vehicle). Furthermore, all animals, except the $\mathrm{N}$ group were exposed to whole body radiation ( 5 Gy). The body weights of all animals were determined a day prior to irradiation and every third day thereafter. One week after irradiation, five animals in each group $(n=5)$ were sacrificed by cervical dislocation, and the remaining surviv-

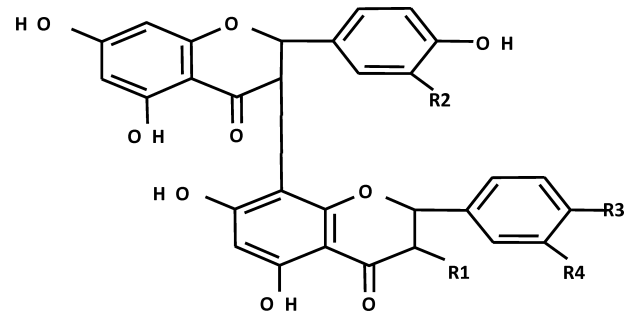

$\begin{array}{lllll} & \text { R1 } & \text { R2 } & \text { R3 } & \text { R4 } \\ \text { GB1 } & \text { OH } & \text { H } & \text { OH } & \text { H } \\ \text { GB2 } & \text { OH } & \text { H } & \text { OH } & \text { OH } \\ \text { Kolaflavanone } & \text { OH } & \text { H } & \text { OMe } & \text { OH }\end{array}$

Fig. 1. Structure of Kolaviron (KV)

ing animals sacrificed after 8 weeks of irradiation.

Preparation of Post-mitochondrial Fraction (PMF) Whole Brain was immediately dissected out and washed in ice-cold $1.15 \% \mathrm{KCl}$ to remove blood stains. The brain tissues were weighed and $10 \%$ tissue homogenate was prepared with $5 \mathrm{~mm}$ phosphate buffer, $\mathrm{pH}$ 7.4. After centrifugation at $10000 \boldsymbol{g}$ for $15 \mathrm{~min}$ to obtain post-mitochondrial supernatant fraction (PMF), the clear supernatant was used to measure the protein contents, levels of lipid peroxidation (LPO), superoxide dismutase (SOD), catalase (CAT), glutathione- $S$ transferase (GST) and reduced glutathione (GSH).

Preparation of Serum Rats were dissected and blood collected from inferior vena cava of the heart into clean centrifuge tubes and allowed to stand for $1 \mathrm{~h}$. Serum was prepared by centrifugation at $3000 \boldsymbol{g}$ for $15 \mathrm{~min}$ in a mesenchymal stromal cells (MSC) bench centrifuge. The clear supernatant was used for the estimation of serum enzymes (ALT and AST), urea and creatinine.

Protein Determination Protein contents of serum and PMF were determined according to Lowry et al. ${ }^{21)}$ using bovine serum albumin as a standard. Briefly, the method involved the reduction of phospho-18 molybdic tungstic complex by phenolic groups present in amino acids to blue complex at alkaline $\mathrm{pH}$. The absorbance of the complex was read at $720 \mathrm{~nm}$.

Alanine and Aspartate Aminotransferases (ALT and AST) Determination Serum ALT and AST activities were determined using a combination of the methods of Mohun and Cook $^{22)}$ and Reitman and Frankel. ${ }^{23)}$ Briefly, $1.0 \mathrm{ml}$ of the enzyme substrate was pre-incubated at $37^{\circ} \mathrm{C}$ for $10 \mathrm{~min}$ in both test and blank tubes. To the test, $0.2 \mathrm{ml}$ of serum was added and incubated for another $60 \mathrm{~min}$. For AST, $0.05 \mathrm{ml}$ of aniline citrate reagent was added and then followed by $0.2 \mathrm{ml}$ of serum to the blank. (For ALT, the incubation time was $30 \mathrm{~min}$ and aniline citrate reagent was not added). The pyruvate formed was reacted with $1.0 \mathrm{ml}$ of 2,4-dinitrophenyl hydrazine to form a coloured hydrazone. The reaction was stopped with $10.0 \mathrm{ml}$ of $0.4 \mathrm{~N} \mathrm{NaOH}$ and the absorbance read at $505 \mathrm{~nm}$ using spectrophotometer.

Creatinine and Urea Determination Serum creatinine and urea levels were estimated by the methods of Jaffe ${ }^{24)}$ and, Talke and Schubert, ${ }^{25)}$ respectively.

Glutathione-S-transferase (GST) Determination The PMF GST level was determined spectrophotometrically at 
$37^{\circ} \mathrm{C}$ according to the procedure of Habig et $a .^{26)}$ The method is based on the rate of conjugate formation between GSH and 1-chloro-2,4-dinitrobenzene (CDNB). Thirty microliters of reduced GSH was introduced into the blank and test tubes. It was followed by $150 \mu \mathrm{l}$ of enzyme substrate (1chloro-2,4-dinitrobenzene) to blank and test. Then $30 \mu \mathrm{l}$ of enzyme source (PMF) was added to the test alone, and the tubes were made up to total volume of $3.0 \mathrm{ml}$ with $0.1 \mathrm{M}$ phosphate buffer, $\mathrm{pH}$ 6.5. The reaction was allowed to run for $60 \mathrm{~s}$ before the absorbance was read against the blank at $340 \mathrm{~nm}$.

Reduced Glutathione (GSH) Determination PMF GSH level was assayed by measuring the rate of formation of chromphoric product in a reaction between $5,5^{1}$-dinitrobis-2nitrobenzoic acid (DTNB) and free sulphydryl groups (such as GSH) at $412 \mathrm{~nm}$ as described by Moron et al. ${ }^{27)}$ To the homogenate, $10 \%$ trichloroacetic acid was added and centrifuged. $1.0 \mathrm{ml}$ of the supernatant was treated with $0.5 \mathrm{ml}$ Ellman's reagent $\left(19.8 \mathrm{mg}\right.$ of $5,5^{1}$-dinitrobis-2-nitrobenzoic acid in $100 \mathrm{ml}$ of $0.1 \%$ sodium nitrite) and $3.0 \mathrm{ml}$ of $0.2 \mathrm{M}$ phosphate buffer $(\mathrm{pH} 8.0)$. The absorbance of the colour formed was read at $412 \mathrm{~nm}$.

Superoxide Dismutase and Catalase Determination Superoxide dismutase activity (SOD) was measured by the nitro blue tetrazolium (NBT) reduction method of McCord and Fridovich, ${ }^{28)} 0.5 \mathrm{ml}$ of tissue homogenate was mixed with ethanol and chloroform mixture and then centrifuged. To the supernatant, $0.025 \mathrm{M}$ sodium pyrophosphate buffer ( $\mathrm{pH}$ 8.3), phenazine methosulphate, nitroblue tetrazolium and NADH were added and incubated at $30^{\circ} \mathrm{C}$ for $90 \mathrm{~s}$. The reaction was stopped by the addition of glacial acetic acid and mixed with $n$-butanol. The intensity of the chromogen in the butanol was measured at $560 \mathrm{~nm}$. Catalase (CAT) activity was assayed by measuring the rate of decomposition of hydrogen peroxide at $240 \mathrm{~nm}$ as described by Aebi. ${ }^{29)}$ The reaction mixture contained phosphate buffer $(0.01 \mathrm{M}, \mathrm{pH} 7.0)$, tissue homogenate and $2 \mathrm{M} \mathrm{H}_{2} \mathrm{O}_{2}$. The reaction was stopped by the addition of dichromate-acetic acid reagents $(5 \%$ potassium dichromate and glacial acetic acid were mixed in a ratio of $1: 3$ ).

Lipid Peroxidation (LPO) Determination LPO in the PMF was assayed spectrophotometrically by the thiobarbituric acid reactive substances (TBARS) method, as described by Walls et al. ${ }^{30)} 1.0 \mathrm{mg} / \mathrm{ml}$ final concentration of sample (PMF) was incubated for $6 \mathrm{~h}$ at $37^{\circ} \mathrm{C}$ with or without $1 \mathrm{~mm}$ $\mathrm{FeSO}_{4} ; 1 \mathrm{~mm}$ ascorbate and $0.2 \mathrm{M} \mathrm{H}_{2} \mathrm{O}_{2}$ (final concentration). $0.5 \mathrm{ml}$ of $0.75 \%$ TBA in $0.1 \mathrm{M} \mathrm{HCl}$ was added to $0.5 \mathrm{ml}$ of the incubation mixture already quenched with $0.5 \mathrm{ml}$ of $10 \%$ trichloroacetic acid (TCA). The mixture was heated at 90 $95^{\circ} \mathrm{C}$ for $25 \mathrm{~min}$ in a boiling water bath and then cooled. The mixture was then centrifuged at $3000 \mathrm{rpm}$ for $10 \mathrm{~min}$, and the absorbance of supernatant read at $532 \mathrm{~nm}$.

Statistical Analysis All values were expressed as the mean \pm S.D. of five animals sacrificed after 1 week of irradiation and 3-6 animals after 8 weeks of irradiation. Data were analyzed using one-way ANOVA followed by the post-hoc Duncan multiple range test for analysis of biochemical data using spss (10.0) statistical software. Values were considered statistically significant at $p<0.05$.

\section{RESULTS}

Table 1 shows that the body weight of irradiated animals significantly $(p<0.05)$ decreased after 1 and 8 weeks of exposure by $20 \%$ and $46 \%$, respectively, relative to normal. Treatment with $\mathrm{KV}$ and $\mathrm{VC}$ attenuated the $\gamma$-radiation induced weight loss after 1 week of exposure. In Table 2, there were no significant $(p>0.05)$ changes in the brain protein contents, total and relative weight of irradiated animals after 1 week of exposure. However, significant decreases $(p<0.05)$ were observed in the brain protein contents, total and relative weight of the irradiated animals after 8 weeks of exposure. These observed decreases were significantly $(p<0.05)$ ameliorated in animals treated with $\mathrm{KV}$ and $\mathrm{VC}$. In Table 3, $\gamma$-irradiation caused significant increases $(p<0.05)$ in the activities of serum ALT and AST after 8 weeks of exposure. Precisely, serum ALT and AST were increased by $69 \%$ and $82 \%$, respectively, after 8 weeks of irradiation. However, the $\gamma$-radiation-induced increases in ALT and AST

Table 1. Effect of Kolaviron, a Biflavonoid Complex from Garcinia kola Seeds, on the Body Weight of Wistar Albino Rats before and after Exposure to $\gamma$-Radiation (5 Gy)

\begin{tabular}{cccc}
\hline \hline \multirow{3}{*}{ Grouping } & \multicolumn{3}{c}{ Body weight $(\mathrm{g})$} \\
\cline { 2 - 4 } & $\begin{array}{c}\text { Before } \\
\text { irradiation } \\
(n=11)\end{array}$ & $\begin{array}{c}\text { 1 week after } \\
\text { irradiation } \\
(n=5)\end{array}$ & $\begin{array}{c}8 \text { weeks after } \\
\text { irradiation } \\
(n=3-6)\end{array}$ \\
\hline $\mathrm{N}$ & $209.1 \pm 6.13$ & $225.7 \pm 3.31$ & $288.5 \pm 8.00$ \\
$\mathrm{KV}$ & $220.1 \pm 8.64$ & $226.3 \pm 7.01$ & $185.1 \pm 5.33^{*}$ \\
$\mathrm{RA}$ & $223.0 \pm 6.09$ & $181.4 \pm 3.07^{*}, \#$ & $157.1 \pm 5.66^{*}, \#$ \\
VC & $211.3 \pm 7.45$ & $207.2 \pm 7.083$ & $178.9 \pm 3.08^{*}$
\end{tabular}

Values are mean \pm S.D. of $n=3-11$ according to the groups. Where $n=6,5,3$ and 4 for N, KV, RA and VC groups, respectively, after 8 weeks of irradiation. * Significantly different from normal $(p<0.05)$. \#Significantly different from KV and VC $(p<0.05)$ $\mathrm{N}=$ normal (un-irradiated animals), $\mathrm{KV}=$ kolaviron $(250 \mathrm{mg} / \mathrm{kg}), \mathrm{RA}=$ irradiated alone, $\mathrm{VC}=$ vitamin $\mathrm{C}(250 \mathrm{mg} / \mathrm{kg})$.

Table 2. Effect of Kolaviron, a Biflavonoid Complex from Garcinia kola Seeds, on the Weight of Brain, Relative Weight and Protein Contents in Rats Exposed to $\gamma$-Radiation (5 Gy)

\begin{tabular}{|c|c|c|c|c|c|c|}
\hline \multirow{2}{*}{ Grouping } & \multicolumn{2}{|c|}{ Protein content (mg/g tissue) } & \multicolumn{2}{|c|}{ Weight of brain $(\mathrm{g})$} & \multicolumn{2}{|c|}{ Relative weight of brain ( $\%$ of body weight) } \\
\hline & 1 week & 8 weeks & 1 week & 8 weeks & 1 week & 8 weeks \\
\hline $\mathrm{N}$ & $0.60 \pm 0.06$ & $0.63 \pm 0.07$ & $2.51 \pm 0.82$ & $2.91 \pm 0.83$ & $1.11 \pm 0.24$ & $1.35 \pm 0.40$ \\
\hline $\mathrm{KV}$ & $0.54 \pm 0.04$ & $0.58 \pm 0.08$ & $2.67 \pm 0.59$ & $2.51 \pm 0.60$ & $1.18 \pm 0.27$ & $1.36 \pm 0.41$ \\
\hline RA & $0.59 \pm 0.07$ & $0.24 \pm 0.03^{* * * *}$ & $1.99 \pm 0.79$ & $1.43 \pm 0.38^{*, \#}$ & $1.09 \pm 0.37$ & $0.91 \pm 0.22 *$,\# \\
\hline $\mathrm{VC}$ & $0.58 \pm 0.05$ & $0.31 \pm 0.03 *$ & $2.11 \pm 0.72$ & $2.18 \pm 0.67$ & $1.09 \pm 0.41$ & $1.22 \pm 0.47$ \\
\hline
\end{tabular}

Values are mean \pm S.D. of $3-6$ animals per group. Where $n=5$ for all groups after 1 week of irradiation, and $n=6,5,3$ and 4 for N, KV, RA and VC groups, respectively, after 8 weeks of irradiation. * Significantly different from normal $(p<0.05)$. $* *$ Significantly different from KV $(p<0.05)$. \# Significantly different from KV and VC $(p<0.05)$. N $=$ normal (un-irradiated animals), $\mathrm{KV}=$ kolaviron $(250 \mathrm{mg} / \mathrm{kg}), \mathrm{RA}=$ irradiated alone, $\mathrm{VC}=$ vitamin $\mathrm{C}(250 \mathrm{mg} / \mathrm{kg})$. 
Table 3. The Effect of Kolaviron, a Biflavonoid Complex from Garcinia kola Seeds, on the Levels of Serum Aminotransferases, Creatinine and Urea in Rats Exposed to $\gamma$-Radiation (5 Gy)

\begin{tabular}{|c|c|c|c|c|c|c|}
\hline \multirow{2}{*}{ Grouping } & \multicolumn{2}{|c|}{$\operatorname{ALT}(\mathrm{U} / \mathrm{l})$} & \multicolumn{2}{|c|}{$\operatorname{AST}(\mathrm{U} / \mathrm{l})$} & \multicolumn{2}{|c|}{ Creatinine (mmol/l) } \\
\hline & 1 week & 8 weeks & 1 week & 8 weeks & 1 week & 8 weeks \\
\hline $\mathrm{N}$ & $46.21 \pm 8.17$ & $52.43 \pm 10.35$ & $219.53 \pm 21.48$ & $215.15 \pm 18.52$ & $436.60 \pm 36.18$ & $473.54 \pm 20.30$ \\
\hline $\mathrm{KV}$ & $47.80 \pm 7.58$ & $61.05 \pm 9.94$ & $209.33 \pm 17.02$ & $227.08 \pm 16.35$ & $424.36 \pm 25.11$ & $461.20 \pm 30.05$ \\
\hline RA & $49.35 \pm 9.27$ & $88.49 \pm 11.27^{*, \#}$ & $232.80 \pm 20.71$ & $391.56 \pm 23.58^{*, \#}$ & $490.61 \pm 32.40$ & $508.07 \pm 21.01$ \\
\hline $\mathrm{VC}$ & $48.20 \pm 8.43$ & $55.36 \pm 9.80$ & $206.42 \pm 19.59$ & $223.33 \pm 19.60$ & $437.11 \pm 18.90$ & $490.63 \pm 31.80$ \\
\hline
\end{tabular}

Values are mean \pm S.D. of $3-6$ animals per group. Where $n=5$ for all groups after 1 week of irradiation, and $n=6,5,3$ and 4 for N, KV, RA and VC groups, respectively, after 8 weeks of irradiation. $*$ Significantly different from normal $(p<0.05)$. \# Significantly different from $\mathrm{KV}$ and $\mathrm{VC}(p<0.05)$. N $=$ normal $($ un-irradiated animals), $\mathrm{KV}=\mathrm{kolaviron}$ $(250 \mathrm{mg} / \mathrm{kg}), \mathrm{RA}=$ irradiated alone, $\mathrm{VC}=$ vitamin $\mathrm{C}(250 \mathrm{mg} / \mathrm{kg})$.

Table 4. Effect of Kolaviron (KV), a Biflavonoid Complex from Garcinia kola Seeds, on the Antioxidant Enzymes in Wistar Albino Rats before and after Exposure to $\gamma$-Radiation (5 Gy)

\begin{tabular}{ccccc}
\hline \hline & \multicolumn{3}{c}{ KV-treated rats } & \\
\cline { 2 - 4 } $\begin{array}{c}\text { Antioxidant } \\
\text { indices }\end{array}$ & $\begin{array}{c}\text { Before } \\
\text { irradiation } \\
(n=5)\end{array}$ & $\begin{array}{c}\text { 1 week after } \\
\text { irradiation } \\
(n=5)\end{array}$ & $\begin{array}{c}8 \text { weeks after } \\
\text { irradiation } \\
(n=3-6)\end{array}$ & $\begin{array}{c}\text { Normal rats } \\
(n=5)\end{array}$ \\
\hline GSH & $4.86 \pm 0.73^{*}$ & $3.43 \pm 0.52$ & $2.45 \pm 0.47^{*}$ & $3.46 \pm 0.50$ \\
GST & $6.91 \pm 0.81^{*}$ & $5.11 \pm 0.66$ & $4.01 \pm 0.71^{*}$ & $5.54 \pm 1.03$ \\
CAT & $0.32 \pm 0.04$ & $0.33 \pm 0.04$ & $0.23 \pm 0.05^{*}$ & $0.35 \pm 0.05$ \\
SOD & $6.31 \pm 1.12$ & $5.78 \pm 1.02$ & $5.34 \pm 1.22$ & $6.89 \pm 0.78$ \\
LPO & $2.05 \pm 0.47^{*}$ & $3.74 \pm 0.61$ & $6.49 \pm 0.89^{*}$ & $3.05 \pm 0.65$ \\
\hline
\end{tabular}

Values are mean \pm S.D. of $n=3-11$ according to the groups. $*$ Significantly different from normal $(p<0.05)$. Units: GSH $(\mu \mathrm{g} / \mathrm{mg}$ protein $)$, GST $(\mathrm{mmol} / \mathrm{min} / \mathrm{mg}$ protein), $\mathrm{CAT}(\mu \mathrm{mol} / \mathrm{min} / \mathrm{mg}$ protein), SOD (U/mg protein), LPO ( $\mu \mathrm{mol} / \mathrm{mg}$ protein).

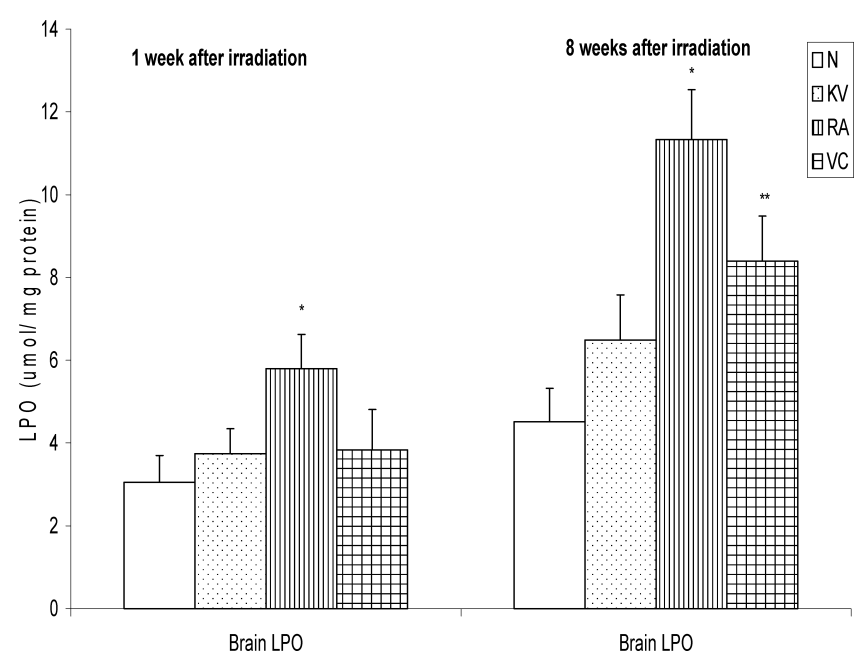

Fig. 2. Effect of Kolaviron, a Biflavonoid Complex from Garcinia kola Seeds, on the Levels of Lipid Peroxidation in Brain of Rats Exposed to Gamma Radiation (5 Gy)

$*$ Significantly different from normal, $\mathrm{KV}$ and $\mathrm{VC}(p<0.05)$. ** Significantly different from RA $(p<0.05)$.

activities were significantly $(p<0.05)$ attenuated in $\mathrm{KV}$ - and VC-treated animals after 8 weeks of exposure. Furthermore, there were no significant differences $(p>0.05)$ in the levels of serum creatinine of irradiated animals when compared to others after 1 and 8 weeks of irradiation. In Table 4, pretreatment with $\mathrm{KV}$ boosted the antioxidant status of the rats as evidenced by significantly elevation of GSH and GST levels when compared to the normal.

In Figs. 2 and 3, there were significant increases $(p<0.05)$

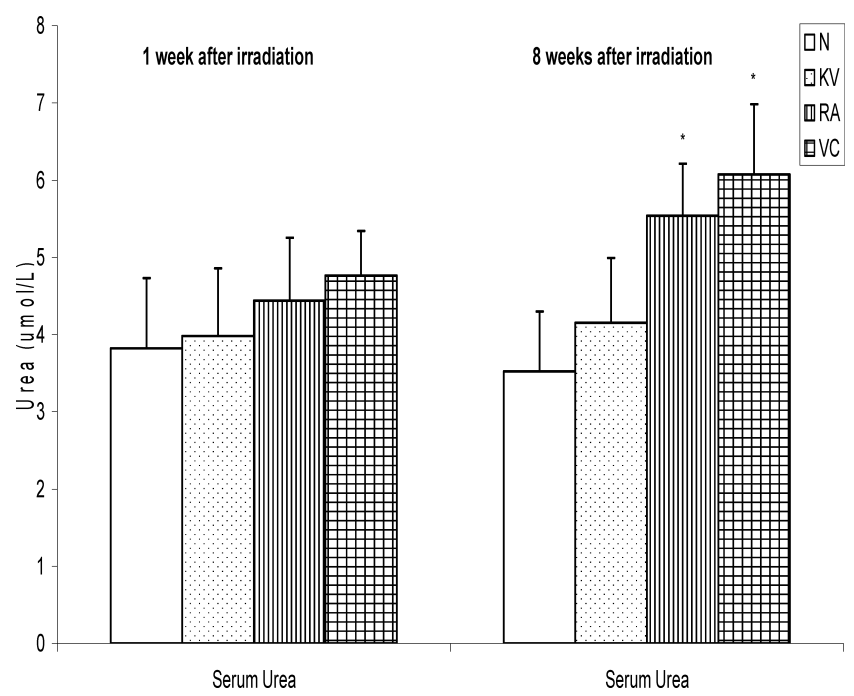

Fig. 3. Effect of Kolaviron, a Biflavonoid Complex from Garcinia kola Seeds, on the Levels of Serum Urea in Rats Exposed to Gamma Radiation (5 Gy)

* Significantly different from normal and KV $(p<0.05)$.

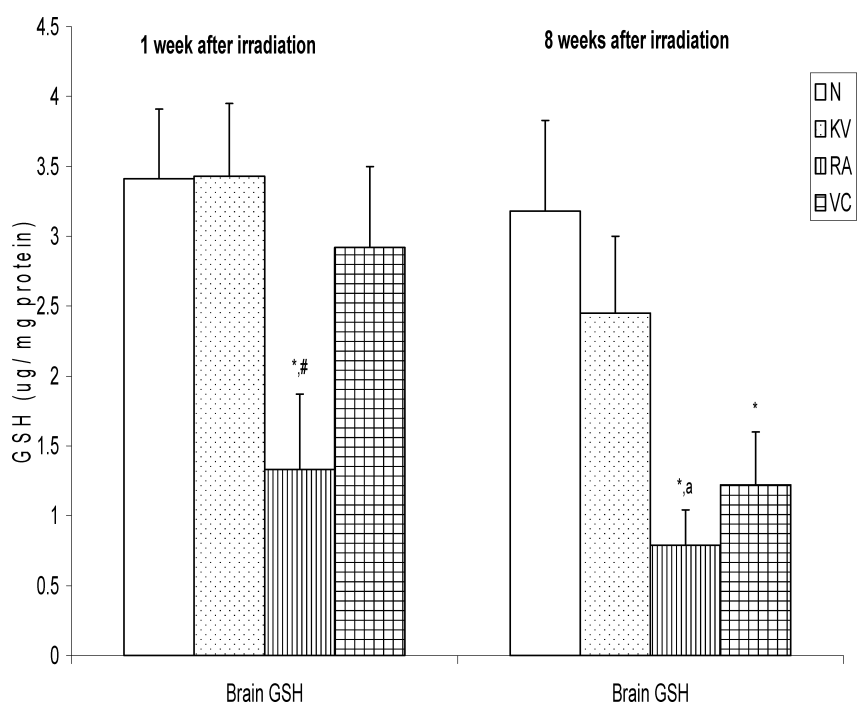

Fig. 4. Effect of Kolaviron, a Biflavonoid Complex from Garcinia kola Seeds, on the Levels of Reduced Glutathione in Brain of Rats Exposed to Gamma Radiation (5 Gy)

\# Significantly different from KV and VC $(p<0.05)$. * Significantly different from normal $(p<0.05)$. a Significantly different from KV $(p<0.05)$. 


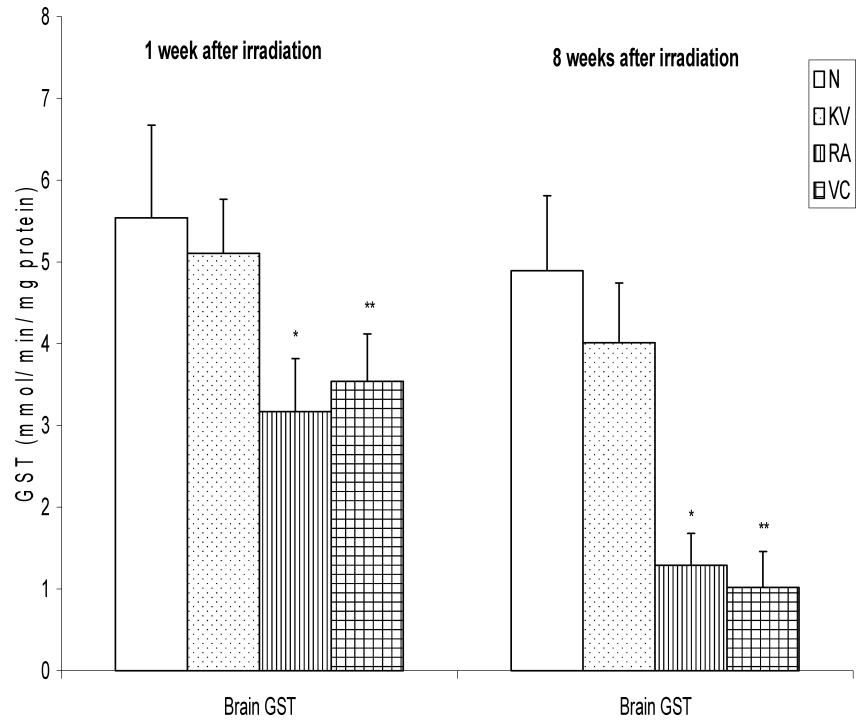

Fig. 5. Effect of Kolaviron, a Biflavonoid Complex from Garcinia kola Seeds, on the Levels of Glutathione-S-transferase in Brain of Rats Exposed to Gamma Radiation (5 Gy)

$*$ Significantly different from normal and KV $(p<0.05)$. ** Significante difference from RA $(p<0.05)$.

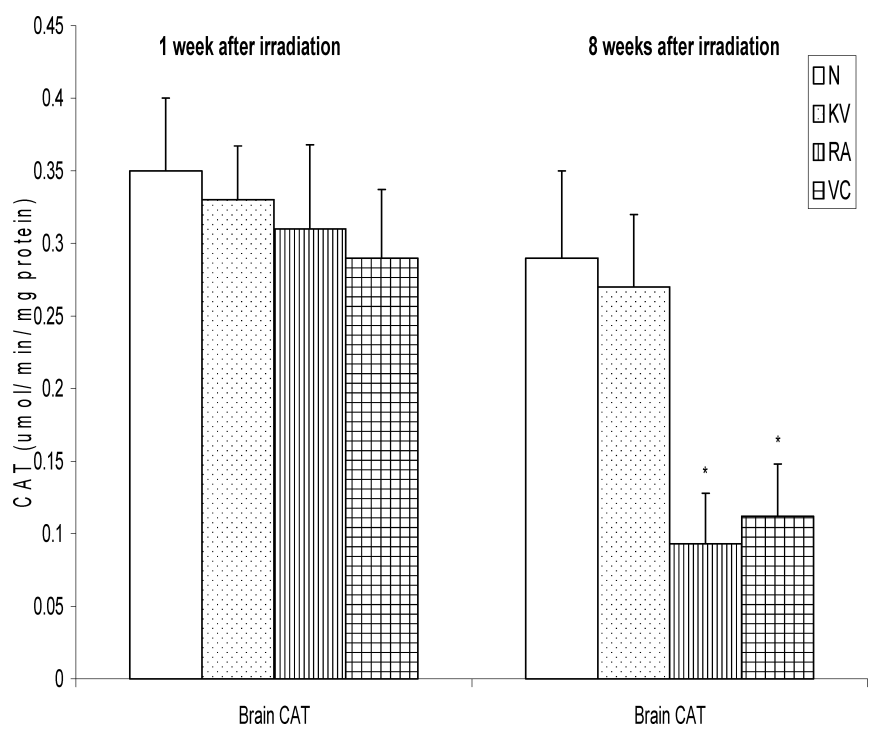

Fig. 6. Effect of Kolaviron, a Biflavonoid Complex from Garcinia kola Seeds, on the Activities of Catalase in Brain of Rats Exposed to Gamma Radiation (5 Gy)

$*$ Significantly different from normal and KV $(p<0.05)$

in the levels of brain lipid peroxidation (LPO) and serum urea of irradiated animals when compared to normal. Specifically, brain LPO increased by $90 \%(5.80 \pm 0.82$ versus $3.05 \pm 0.65)$ and $151 \%(11.33 \pm 1.21$ versus $4.51 \pm 0.81)$ after 1 and 8 weeks of irradiation, respectively, while the level of serum urea in irradiated animals was increased by $57 \%$ $(5.54 \pm 0.67$ versus $3.52 \pm 0.78)$ after 8 weeks of exposure. Treatment with KV and VC significantly $(p<0.05)$ ameliorated the radiation-induced increases in the levels of brain LPO. Also in KV-treated animals, the radiation-induced increase in serum urea was ameliorated. Importantly, in KVtreated animals, the levels of LPO and urea were restored to values that are statistically similar to normal.

In Figs. 4 and $5, \gamma$-radiation caused significant $(p<0.05)$

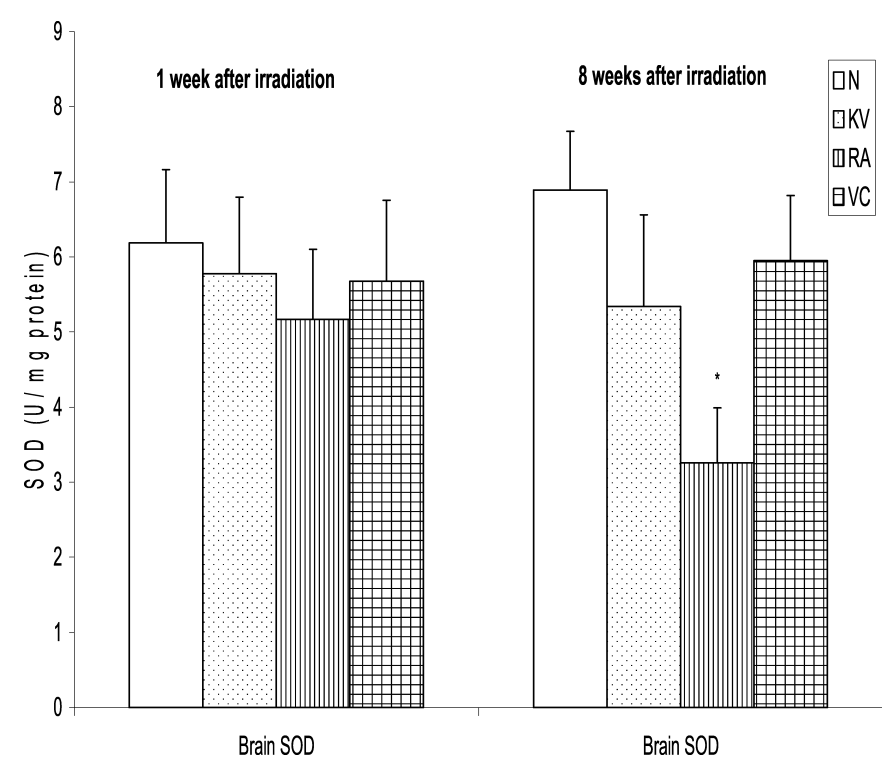

Fig. 7. Effect of Kolaviron, a Biflavonoid Complex from Garcinia kola Seeds, on the Activities of Superoxide Dismutase in Brain of Rats Exposed to Gamma Radiation (5 Gy)

* Significantly different from normal, KV and KV $(p<0.05)$.

decreases in the levels of brain reduced glutathione (GSH) and glutathione- $S$-transferase (GST) of irradiated animals. Brain GSH and GST levels were decreased by $61 \%$ $(1.33 \pm 0.54$ versus $3.41 \pm 0.50)$ and $43 \%$ ( $3.17 \pm 0.65$ versus $5.54 \pm 1.13)$ after 1 week, and by $75 \%(0.79 \pm 0.25$ versus $3.18 \pm 0.61)$ and $74 \%(1.29 \pm 0.39$ versus $4.89 \pm 0.92)$ after 8 weeks of exposure, respectively. Treatment with KV completely restored the brain GSH and GST levels of irradiated animals after 1 and 8 weeks of exposure, while treatment with VC could only restore the depleted brain GSH levels after 1 week of irradiation (Figs. 4, 5).

In Figs. 6 and 7, $\gamma$-radiation decreased the brain CAT and SOD levels of irradiated animals by $68 \%(0.093 \pm 0.04 \mathrm{ver}$ sus $0.290 \pm 0.05)$ and $53 \%$ (3.26 0.92 versus $6.89 \pm 0.89)$, respectively, after 8 weeks of exposure. The radiationinduced decrease in brain CAT was significantly $(p<0.05)$ attenuated in KV-treated animals, while both $\mathrm{KV}$ - and VCtreated animals had their SOD levels elevated by $64 \%$ $(5.34 \pm 1.02$ versus $3.26 \pm 0.73)$ and $83 \%(5.95 \pm 0.87$ versus $3.26 \pm 0.73$ ), respectively, when compared to irradiated and untreated animals after 8 weeks of irradiation.

\section{DISCUSSION}

During radiotherapy normal brain can undergo undesirable tissue injury especially in the treatment of cerebral tumors. Moreover, central nervous system detrimental effects have been found in radiation exposed children after Hiroshima and Nagasaki atomic bomb blasts as well as after the Chernobyl accident. ${ }^{31,32)}$ For these reasons, the present study aimed at exploring the possible radioprotective effect of kolaviron (a biflavonoid from Garcinia kola seeds) on $\gamma$-radiationinduced oxidative stress in brain of rats. The goal of radiation treatment is to deliver precisely measured doses of ionizing radiation to a defined tumor volume with minimum acceptable injury to surrounding healthy tissue while eliminating the tumor cells. ${ }^{33)}$ Ionizing radiation is known to induce ox- 
idative stress through generation of ROS including superoxide, hydroxyl radicals, singlet oxygen and hydrogen peroxide. These free radicals react with critical cellular components, such as DNA, RNA, proteins and membranes, leading to cell dysfunction and death. Excess ROS may lead to an imbalance in pro-oxidant and antioxidant status in the cells. $^{34)}$

Today, there is considerable interest in free radical mediated damage to biological systems due to xenobiotics or radiation exposure. A large number of xenobiotics have been identified to have potential to generate free radicals in biological systems. ${ }^{35)}$ Free radicals have become an attractive means to explain the toxicity of numerous xenobiotics. Some of these free radicals interact with various tissue components, resulting in dysfunction and injury to the brain and other organs. Lipid peroxidation has been suggested as one of the molecular mechanisms involved in radiation-induced toxicity. ${ }^{12)}$ In the present study; increased levels of malondialdehyde (MDA, an index of lipid peroxidation) was observed in brain tissues of $\gamma$-irradiated rats. This may be due to the free radical attack on cell membrane phospholipids and circulating lipids and, thus, MDA acts as a sensitive biomarker for oxidative stress that occurs as part of the pathogenesis of various diseases. ${ }^{36,37)}$ The present study found that KV from Garcinia kola seeds and VC significantly reduced the MDA levels. The decrease in the activities of SOD, CAT and GST, and the decreased level of GSH in the brain tissues may be due to their utilization by the enhanced production of ROS $^{38)}$ In agreement with this finding, Bhatia and Jain ${ }^{39)}$ observed a significant depletion in the antioxidant system, and an increased lipid peroxides in animals exposed to whole body $\gamma$-irradiation. The decreased levels of GSH in brain of irradiated animals may have resulted from the activity of GST and glutathione peroxidase (GPx) in reducing lipid hydroperoxide to stable non-radical lipid alcohols or GSH is directly utilized as an antioxidant in terminating free radical reaction initiated by irradiation. Under normal conditions, the inherent defense system, including glutathione and the antioxidant enzymes ability to protect against oxidative damage. These endogenous enzymes, namely SOD, CAT, GST and GPx, are responsible for the deactivation of ROS and are the primary antioxidant system in cells. SOD catalyzes dismutation of the superoxide ion $\left(\mathrm{O}_{2}^{--}\right)$and converts it to $\mathrm{H}_{2} \mathrm{O}_{2}{ }^{40)}$ In this study, SOD activity was decreased by $\gamma$-irradiation, but it was significantly restored when rats were given $\mathrm{KV}$ and $\mathrm{VC}$ after 8 weeks of exposure. In the antioxidant cascade, $\mathrm{CAT}$ decomposes $\mathrm{H}_{2} \mathrm{O}_{2}$ to $\mathrm{H}_{2} \mathrm{O}$ and $\mathrm{O}_{2}{ }^{41)}$ Administration of $\mathrm{KV}$ and $\mathrm{VC}$ significantly restored the radiationinduced suppression of CAT. GSTs are family of soluble proteins, which conjugate xenobiotics with glutathione. ${ }^{42)}$ Metabolites after glutathionylation are more hydrophilic and thus biologically inactive. Therefore, they are readily excreted in bile or urine as conjugates. This action is thus believed to be a major mechanism for the detoxification of reactive species. It was observed that the administration of $\mathrm{KV}$ and VC significantly inhibited GSH depletion in brain of irradiated animals and up-regulated GST activity, pointing to the protective role of $\mathrm{KV}$ against $\gamma$-radiation-induced adverse reactions in the exposed animals.

It is clear that $\gamma$-irradiation caused significant increases in the levels of serum ALT, AST and urea, while the total pro- tein contents of brain dropped significantly after 8 weeks of exposure. These parameters measure the excretory and synthetic functions of the liver and, indicate an injury, impaired functions and damage of liver of irradiated animals. It is not surprising that the liver functions were impaired in the irradiated animals knowing fully well that ROS are generated during radiation exposure. The ability of KV to ameliorate radiation-induced increases in serum ALT, AST and urea levels, and also restore the protein contents of irradiated animals point to its possible protective role in these animals. It is therefore reasonable to state that the oxidative stress elicited by irradiation might have been nullified due to the antioxidant activity of KV. In addition, the ability of VC to attenuate the antioxidants status of the irradiated animals further confirmed its antioxidant and protective effects.

In conclusion, the current study finds kolaviron (biflavonoid from Garcinia kola seeds) protective against $\gamma$ radiation induced oxidative stress in brain of exposed rats. Therefore, the consumption of Garcinia kola seeds may be encouraged in patients undergoing radiotherapy to improve general health conditions.

Acknowledgements This study was partly supported by the Senate Research Grant, University of Ibadan, Ibadan, Nigeria given to OAA (SRG/COM/2006/36A).

\section{REFERENCES}

1) Barker S., Weinfeld M., Zheng J., Li Murray D., J. Biol. Chem., 280, 33826-33838 (2005).

2) Gracy R. W., Talent J. M., Kong Y., Conrad C. C., Mutat. Res., 428, $17-22$ (1999).

3) Cerutti P. A., Eur. J. Clin. Invest., 21, 1-5 (1991).

4) Finkel T., Holbrook N. J., Nature (London), 408, 239-247 (2000).

5) Martindale J. L., Holbrook N. J., J. Cell. Physiol., 192, 1-15 (2002).

6) Nicholas J., "X-ray, CT, Nuclear Medicine and PET, and MRI," Part II, W. B. Saunders Company, Philadelphia, PA, 2004.

7) Jagetia G. C., Baliga M. S., Venkateshi P., Ulloor J. N., Radiat. Res., 160, 584-592 (2003).

8) Jagetia G. C., Venkatesh P., Baliga M. S., Integr. Cancer Ther, 3, 323 -332 (2004).

9) Goel C. H., Prasad J., Singh S., Sagar R. K., Agrawala P. K., Bala M., Sinhá A. K., Dogra R., J. Radiat. Res., 45, 61-68 (2004).

10) Hari Kumar K. B., Kuttan R., J. Radiat. Res., 45, 133-139 (2004).

11) Krishna A., Kumar A., J. Radiat. Res., 46, 233-239 (2005).

12) Adaramoye O., Ogungbenro B., Anyaegbu O., Fafunso M., J. Radiat. Res., 49, 123-131 (2008).

13) Iwu M. M., Experientia, 41, 679-700 (1985).

14) Cotterhill P. J., Scheinmann F., Stenhouse T. A., J. Chem. Soc., Perkin Trans. 1, 1978, 246-247 (1978).

15) Iwu M. M., Igboko O. A., Onwuchekwa U., Okunji C. O., J. Ethnopharmacol., 21, 127-142 (1987).

16) Adaramoye O. A., Adeyemi E. O., Basic Clin. Pharmacol. Toxicol., 98, 135-141 (2006).

17) Adaramoye O. A., Nwaneri V. O., Anyanwu K. C., Farombi E. O., Emerole G. O., Clin. Exp. Pharmacol. Physiol., 32, 40-46 (2005a).

18) Adaramoye O. A., Farombi E. O., Adeyemi E. O., Emerole G. O., Pak. J. Med. Sci., 21, 331-339 (2005b).

19) Farombi E. O., Nwaokeafor I. A., Clin. Exp. Pharmacol. Physiol., 32, $667-674$ (2005).

20) Iwu M. M., Igboko O. A., Okunji C. O., Tempesta M. S., J. Pharm. Pharmacol., 42, 290-292 (1990).

21) Lowry O. H., Rosenbrough N. J., Farr A. L., Randall R. J., J. Biol. Chem., 193, 265-275 (1951).

22) Mohun A. F., Cook L. J., J. Clin. Pathol., 10, 394-399 (1957).

23) Reitman S., Frankel S., Am. J. Clin. Pathol., 28, 56-63 (1957).

24) Jaffe M., Z. Physiol. Chem., 10, 391-400 (1886).

25) Talke H., Schubert G. E., Klin. Wochschr., 43, 174 (1965). 
26) Habig W. H., Pabst M. J., Jakoby W. B., J. Biol. Chem., 249, 71307139 (1974).

27) Moron M. A., Depierre J. W., Mannervick B., Biochim. Biophys. Acta, 582, 67-78 (1979).

28) McCord J. M., Fridovich I., J. Biol. Chem., 244, 6049-6055 (1969).

29) Aebi H., "Catalase Estimation," ed. by Bergmeyer H. V., Verlag Chemic, New York, 1974, pp. 673-684

30) Walls R., Kumar K. S., Hochstein P., Arch. Biochem. Biophys., 100, $119-128$ (1976).

31) Kimler B. F., Int. J. Radiat. Biol., 73, 423-434 (1998).

32) United Nations Scientific Committee of the Effects of Atomic Radiation (UNSCEAR), "Report to the General Assembly, Sources, Effects and Risks of Ionizing Radiation," Annex H, United Nations Publications, U.S.A., 1993, pp. 805-842.

33) Ertekin M. V., Tekin S. B., Erdogan F., Karslioglu I., Gepdiremen A., Sezen O., J. Radiat. Res., 45, 543-548 (2004).

34) Bhsole S. M., Huilgol N. G., Mishra K. P., Clin. Chim. Acta, 359, 89-
100 (2005).

35) Kehrer J. P., Crit. Rev. Toxicol., 23, 21-48 (1993).

36) Claiborne A., Malinowski D. P., Fridovich I., J. Biol. Chem., 254, 11664-11668 (1979).

37) Valavanidis A., Vlahogianni T., Dassenakis M., Scoullos M., Ecotoxicol. Environ. Saf., 64, 178-189 (2006).

38) Rajendra Prasad N., Menon V. P., Vasudev V., Pugalendi K. V., Toxicology, 209, 225-35 (2005).

39) Bhatia A. L., Jain M., Phytomedicine, 11, 607-615 (2004).

40) Farese A. M., Hunt P., Grab L. B., Mac Vittie T. J., J. Clin. Invest., 97, 2145-2151 (1996).

41) Sicking W., Korth H. G., Jansen G., de Grott H., Sustmann R., Chemistry, 13, 4230-4245 (2007).

42) Nakamura Y., Ohigashi H., Masuda S., Murakami A., Morimitsu Y., Kawamoto Y., Osawa T., Imagawa M., Uchida K., Cancer Res., 60, $219-225$ (2000). 